\title{
Läti rahvalaulud Johann Gottfried Herderi kogus ${ }^{1}$
}

\begin{abstract}
Beata Paškevica
Teesid: Artiklis vaadeldakse, kuidas kujunes Herderi läti rahvalaulude kogu ning millised võisid olla Herderi rahvalaulude avaldamise põhimõtted. Ühtlasi peatutakse rahvalaulu mõiste kujunemisel Läti saksakeelses kultuuriruumis 18. sajandi lõpul ja 19. sajandi alguses. Erilist tähelepanu on pööratud August Wilhelm Hupeli, aga ka Johann Friedrich Hartknochi, Jakob Benjamin Fischeri, Heinrich Baumanni ja Gustav Bergmanni osale läti rahvalaulude üleskirjutamisel ja Herderile saatmisel. Lähemalt kirjeldatakse läti rahvalaulude käsikirjalist tekstikogu Herderi isikuarhiivis, mis asub Berliini Riigiraamatukogu Preisi kultuuripärandi käsikirjade osakonnas. Herderi laulukogu käsikirjade autorid on nüüdseks kõik ka välja selgitatud. Ilmneb, et Hupeli osale läti kultuuriloos tuleks senisest enam tähelepanu pöörata.

Märksõnad: Heinrich Baumann, Gustav Bergmann, Jakob Benjamin Fischer, Johann Gottfried Herder, August Wilhelm Hupel, läti rahvalaulud, rahvalaul, valgustusajastu, Volkslieder / Stimmen der Völker in Liedern
\end{abstract}

"Kogu maailm ja keeled, eriti aga iidne Orient pakuvad algusaegade jälgi, kui vaid on tarvis neile osutada ja neid nimetada."2 (Herder 1990: 230.)

Johann Gottfried Herderi rahvalaulude antoloogias "Volkslieder" (1778-1779) on avaldatud üksteist läti rahvalaulu. ${ }^{3}$ Õieti on need Herderi töötlused läti laulude saksakeelsetest tõlgetest, mis olid talle saadetud 1777/1778. aasta talvel. Artiklis vaadeldaksegi lähemalt neid kogumikus avaldatud laule ja nendega seotud Herderi läti rahvalaulude käsikirjakogu, mis asub Berliini Riigiraamatukogu Preisi kultuuripärandi käsikirjade osakonnas Herderi isikuarhiivis (vt Herder Nachlass XIV: 49-53). 


\section{Läti laulud kogumikus "Volkslieder"}

Herderi koostatud rahvalaulude kogumikus avaldatud läti tekstid on jaotatud kahte ossa: kuus laulu on alajaotuses "Fragmente Lettischer Lieder" (Läti laulude fragmendid), viis laulu aga alajaotuses "Frühlingslied" (Kevadlaul). Neist esimese, Läti laulude fragmendid, pani Herder kokku nn Liivimaa kogumiku (Livländische Sammlung) põhjal. Pealkiri "Liivimaa kogumik" pärineb 1950. aastatest, mil ajaloolane Leonid Arbusow nimetas nõnda Herderile Weimarisse saadetud enam kui kaheksakümnest ${ }^{4}$ läti rahvalaulust ja mõnest vaimulikust laulust ning nende saksakeelsetest tõlgetest koosnevat tekstikogu (Arbusow 1953: 187). Arbusow eeldas, et ka teises (Kevadlaulu) alajaotuses olevate tekstide lätikeelsed versioonid peaksid pärit olema samast Liivimaa kogumikust. Ometi peab tõdema, et seni pole õnnestunud leida "Kevadlaulu" tekste ühestki Herderi käsikirjalisest kogust. Sellest järeldub, et Herderi käsutuses oli veel mõni läti rahvalaulude saadetis, mis on kaduma läinud. Loomulikult pole teada ka selles olnud tekstide arvu. Erinevalt "Kevadlaulu" tekstidest on "Läti laulude fragmentide" originaaltekstid tänaseni alles ja nende käsikirjade saatjad on nüüdseks täielikult välja selgitatud.

"Läti rahvalaulude fragmentide" alajaotuses esitatud kuus teksti on valitud kaheksakümne käsikirjalise teksti hulgast. Võib kujutleda, et ka "Kevadlaul" on koostatud paljudele käsikirjalistele tekstidele tuginedes. Igal juhul tuleb käsikirjade mahtu publitseeritud tekstide hulgaga kõrvutades esile, et avaldatud laulutekstid moodustavad vaid väikese osa läti rahvalaulude üleskirjutustest (kuhu lisanduvad ka mõned vaimulikud laulud ning üks noodistus), mille Herderi koostööpartnerid, selle aja Liivimaa väljapaistvaimad intellektuaalid talle olid saatnud. Tuleb tõdeda, et Herder oli 18. sajandi teise poole olulisim rahvaluulekoguja Euroopas, sealhulgas omaaegsel Liivimaal. Ühtlasi on tema käsikirjaliste rahvalaulude kogu oma mahult selle aja suurim.

Millised olid Herderi rahvalaulu-kogumiku koostamise põhimõtted? Kõnesolevas 1778/1779. aastal välja antud kogumikus asuvad läti rahvalaulud kahe luuletaja loomingu vahel: ühel pool Kreekast pärit Sappho "Fragmente Griechischer Lieder" (Kreeka laulude fragmendid), nagu neid tekste nimetas Herder, teisel pool inglise sentimentalismiajastu luuletaja William Shenstone'i luuletus, millele Herder on andnud saksakeelse pealkirja "Elisabeths Trauer im Gefängnis" (Elisabethi lein vanglas). Sellist läti laulude paigutust on põhjendatud mitmeti. Vanima arusaama järgi üritas Herder "tähtsusetuid" läti tekste muuta õilsamaks, pannes need tunnustatud ja rikka kultuuripärandiga rahvaste tekstide vahele. Teise põhjendusena on pakutud, et Herder lähtus laulude paigutamisel kogumikku kindlast, ent kirjalikult fikseerimata põhimõttest. Näiteks arvestas ta nii tekstide arvu $(3 \times 24 \text { ja } 3 \text { x } 30 \text { teksti })^{5}$ kui ka 
temaatilisi seoseid, kuid kindlasti mitte geograafilist printsiipi. Herderi artiklite kogumiku viimase väljaande kirjastaja ja teaduslike kommentaaride autor Ulrich Gaier (vt Herder 1990: 920 jj) pakub omakorda selgituseks, et Herder lähtus laulutekstide korrastamisel "loomishieroglüüfi" (Schöpfungshieroglyp$h e)^{6}$ printsiibist, mida Herder on käsitlenud artiklis "Älteste Urkunden des Menschengeschlechts" (Vanimad tõendid inimsoost):

Loomishieroglüüf Herderi kirjeldatud seitsme- ja kolmeastmelises kompositsioonis on "poeesia kõrgeim ja lihtsaim ideaal" [---] ning peaks loomisprintsiibina avalduma seal, kus on tegemist inimese elu selliste põhiolukordadega nagu armastus, surm, hirm, ohud, kirg, võim jms, sest laulude segiläbi esitus näitab, et siin on seosed loodud mitte rahvuslike või etniliste eripärade, vaid teatud antropoloogiliste vahekordade järgi, juhul kui üldse eksisteerib mõni erinevaid väikesi tekstikogumeid siduv tegur. ${ }^{7}$ (Herder 1990: 921.)

Uurijad on pakkunud veel teisigi selgitusi Herderi tekstide korrastamisviisile. Siiski ei saa kõrvale jätta ka Herderi enda antud vihjet, mis on avaldatud artiklis "Von Ähnlichkeit der mittleren englischen und deutschen Dichtkunst" (Keskmise inglise ja saksa luulekunsti sarnasusest). Herder kõneleb seal Sappho luule ja leedu rahvalaulu antropoloogilisest sarnasusest, kus mõlemad tekstid räägivad armastusest samavõrra kaunilt ja tõetruult:

Kui proua Sappho ja leedu tüdruk laulavad armastusest samamoodi, siis peab nende laulude seaduspärasus tõesti olema tõele vastav, need on armastuse noodid ja need ulatuvad maailma ääreni. ${ }^{8}$ (Šešplaukis 1962: 316, vrd Herder 1909: 326.)

Olemasolevate andmete põhjal ei ole võimalik taastada Herderi rahvalaulude avaldamise põhimõtteid. Küll aga loodan järgnevas visandada seda, kuidas rahvalaulude väärtustamise idee kujunes, ja ühtlasi näidata rahvalaulu mõiste sisu romantismieelsel ajajärgul.

\section{Herderi rahvalaulualaste vaadete kujunemine}

Romantismieelne arusaam rahvalaulust erines radikaalselt romantilise rahvusluse ajastu rahvalaulu definitsioonist, mis sai aluseks folkloristlikule rahvalaulu-mõistele. Romantismiajastu ja suuremas osas ka 20. sajandi folkloristikale on omane tekstide piiritlemine rahvuse järgi. Herderi arusaam rahvalauludest väljendab seevastu inimkonna ühtekuuluvust igas üksikus kultuuripäranditekstis, kus pärimustekstid kommenteerivad ja täiendavad suuri religioosseid 
tekste, samal ajal neist nii lähtudes kui ka nendega põimudes. Herderi lauluantoloogia "Volkslieder" idee sügavamat olemust kirjeldab tabavalt Ulrich Gaier: "Rahvuslik ja antropoloogiline suundumus pidi sulama ühtseks ideaalseks inimkonna hääleks" (Herder 1990: 844). ${ }^{9}$ Niisiis on rahvalaul Herderi enda formuleeringu kohaselt "rahva, laialipillatud inimkonna hääl” selle kõige laiemas tähenduses, nagu ta kirjutab rahvalaulukogumiku eessõnas (Herder 1880: 22) ${ }^{10}$ Mõistagi peab Herder kui teoloog selle all silmas ka Jumala häält, mis kõlab rahva suu kaudu, väljendades elu kogu mitmekesisust, ja millel on ladina traditsioonis oma ajalugu ning piiramatu tõlgendusruum ütluses vox populi vox dei.

Riia-perioodil (1764-1769) saab Herder esmase tõuke suuremale osale oma loomingulistest plaanidest: "herderlik sünnib just Riias", väidab Kurt Stavenhagen (1922: 13). Riias tegeleb Herder Vana Testamendi uurimisega ning 1769. aastal valmib töö "Über die ersten Urkunden des menschlichen Geschlechts" (Esimestest tõenditest inimsoo kohta). Paralleelselt 1773.-1774. aastal plaanitud väljaandega "Alte Volkslieder" (Vanad rahvalaulud) saab lõpetatud ka töö "Älteste Urkunden des Menschengeschlechts" (Vanimad tõendid inimsoost). Riia-perioodil kirjutatud käsitluse "Über die ersten Urkunden ..." (Esimestest tõenditest...) eessõnas arutleb Herder Esimese Moosese raamatu sünni asjaolude üle, püüdes üldistada arusaama Vana Testamendi, eriti Esimese Moosese raamatu ajaloost, ühtlasi kohaldades seda ka teiste rahvaste vanadele religioossetele tekstidele. Herder kirjutab:

Igaüks rääkis oma isade keeles, vaatas maailma, mis teda ümbritses, mõtles asjadest, mis tundusid talle tähendusrikkad ja sellest, kuidas võiks seda selgitada oma kliimast, rahvusest, oma kogemusest lähtudes: igaüks selgitas neid oma rahva huvide, keele ja tavade kohaselt ${ }^{11}$ (Herder 1993: 13).

Herder vaatleb ka Moosest kui luuletajat (Bultmann 2005: 23 jj). Vana Testamendi ja rahvalaulude abil otsib Herder algallikat, iidset lätet, algust. Teda huvitab üldine küsimus, mille ta formuleerib oma teoses "Journal meiner Reise im Jahr 1769" (Minu 1769. aasta reisi päevik) järgmiselt: “On's olnud vagina hominum'iks põhi või lõuna, hommiku- või õhtumaa? Kus on saanud alguse inimsugu, leiutised, kunstid ja religioonid?"12 (Herder 1994: 17). Ulrich Gaier annab Herderi avaldusele omapoolse selgituse:

Algupärases on näha jumalikkust; rahvas ideaalse mõistena on algupärane kategooria, "rahvalaul" selles mõttes (nagu laulgi on algupärane) on jumaliku väljenduse üks viise, milles see on ilmne, mille sisu on kuuldav, heli tajutav [---] ${ }^{13}$ (Herder 1990: 867). 
Herderi kavatsus oli eemalduda oma kaasajast sinna, "kus need algallikad nähtavale ilmuvad, kus need rahva suust kokku koguti, ja kus need elasid" (Herder 1993: 22). ${ }^{14}$ Järeldub, et Herderi teoloogiline ja antropoloogiline huvi ei pane teda uurima mitte ainult piibliteksti kui heebrea luulet, vaid samal viisil pöördub ta ka teiste rahvaste, sealhulgas tema ühe elukoha, Liivimaa rahva luule poole. Kusjuures algupärasus (alguse ja allika tõend) ei peitu mitte ainult Moosese pärandis või muudes vanades tekstides, vaid ka Shakespeare’i loomingus ning isegi Herderi mõttekaaslaste ja ta endagi loomingus, sest näiteks rahvalaulude kogumikku "Volkslieder" on ta lisanud ka oma luuletuse (Herder 1990: 410-412). ${ }^{15}$ Algupärasus või ka esmakordsus ei ole seega ajaliselt piiritletav. See on pigem eriline tunnetus, nägemus, mida võib leida luules üldiselt. Ühtlasi selgub, et anonüümsus ja kollektiivsus (mis hiljem kujunesid rahvaluule kriteeriumiteks) ei ole Herderi ajal veel rahvalaulu määratlemise tingimusteks (vt lähemalt Paškevica 2008). Autorsuse küsimus või kirjaniku kui elukutse mõiste hakkasid kujunema 18. sajandi lõpus. Nagu paljud teised Herderi ajajärgu autorid, nii käis ka Herder oma kolleegide töödega suhteliselt vabalt ümber.

Kuigi Herderi rahvusliku luule tähtsustamisega seotud hoiakud kaldusid ühtima 19. sajandi romantismi ettekujutusega rahvuse vaimust, ulatuvad need siiski sügavamale, sest Herder üritab mõista inimese suhet luulega üldiselt. Herderi sõber Johann Georg Hamann sõnastas mõtte "luule on inimsoo emakeel" (Hamann 1950 [1762]: 197). Selline Herderi rahvalaulude kontseptsioonis märgatav ajatu ja iga rahvast ülistav lähenemisviis, kus ei lähtuta rahvale antud poliitilisest hinnangust, ei ole Herderi ajajärgule omane, ja on seetõttu tähendusrikas. Herderi arusaama järgi on rahva suuline pärimus, nagu ka Vana Testamendi tekst, mille ta nimetas suulise pärimuse algallikaks, sündinud ühest ja samast traditsioonist: mõlemad väljendavad ühe konkreetse rahva arusaamasid, mistõttu nii Piibli kui ka erinevate rahvaste laulud on ühe ja sama puu erinevad viljad. Siiski ei ole õige väita, et Herderi rahvalaulukogu on pelgalt rahvaste ühtsuse ja samal ajal ka nende vaheliste erinevuste demonstratsioon (see oleks idee, mis tänapäeva Euroopa Liidus väljendub loosungis "ühinenud mitmekesisuses"). Nimelt väljendub rahvalaulude kogumikus "Volkslieder" ka Herderi seisukoht valgustusajastu-omasest arusaamast rahvast kui sotsiaalselt madalamast kihist. Näiteks eesti tekstile on Herder jätnud eesti rahvalaulude kirjapanija ja, nagu hiljem selgub, ka läti tekstide saatja August Wilhelm Hupeli sõnastatud pealkirja "Klage über die Tyrannen der Leibeignen" (Pärisorjade kaebus türannide peale $)^{16}$, mida võib võtta kui Herderi ühiskonna-kriitilist avaldust. Nii osaleb ta baltisaksa aristokraatide talurahva olukorra teemalistes sõnavõttudes nn "filosoofilise sajandi lõpus", nagu seda ajajärku on nimetanud Garlieb Helwig Merkel oma raamatus "Die Letten ...” (Lätlased). 
Kokkuvõtteks võib öelda, et uurides Piiblit kui kirjandusteost, kuuldes läti jaanipäeva- või muid laule (olles külas oma Riia-tuttavate maamõisates), samuti mõeldes erinevate rahvaste luule peale, millele Herder oma elu jooksul palju tähelepanu pühendas, kujunes tal välja arusaam rahvalaulude olemusest. 1767. aastal Riias elades kirjutas ta teose "Fragmente über die neuere deutsche Literatur" (Fragmente uuemast saksa kirjandusest) teise trüki tarvis artiklit, mis siis jäi küll lõpetamata, kuid millele Herderi artiklite kirjastaja ja biograaf Bernhard Suphan andis nimeks "Von den ältesten Nationalgesängen" (Vanimatest rahvuste lauludest, Herder 1899: 148-152). Selles lõpetamata artiklis arutleb Herder mütoloogiliste kujutelmade ja rahva seas lauldavate lugude (sellel ajal ei ole Herder veel loonud mõistet Volkslied) tekkeloo üle, ning kujutleb laule kui "ühtset häält": see esindab inimese kujunema hakkavat hinge sellele vaatamata, et need laulud esindavad erinevaid kultuure ja traditsioone (ibid.: 152).

Ilmneb, et 1778/1779. aasta rahvalaulude väljaanne lähtub Herderi antropoloogilistest ja filoloogilistest huvidest, mis saatsid teda alates õpingutest Königsbergis. Herderi rahvalaulu-antoloogias ei olnud veel sellist poeesia ülistamist, nagu seda kohtab pärast Herderi surma 1807. aastal Karoline Herderi ja Johannes von Mülleri välja antud kogumikus, mis sai pealkirjaks "Stimmen der Völker in Liedern" (Rahvaste hääled lauludes) - see oli “etnoloogiliselt informatiivne" kogumik (Herder 1990: 852). Rahvalaulude kirjapanijatele 18. sajandil tähendas nende tegevus tolle aja mõistes pigem antropoloogilist ettevõtmist, või üritasid nad leida kuuldud tekstidest mõnd muistse ajaloo tõendit. Erilist kunstilist väärtust neile tekstidele veel ei omistatud. Gotthard Friedrich Stenderile toetudes võib öelda, et neid peeti lihtsateks ja naiivseteks lauludeks ning need olid asendatavad kunstilisemalt viimistletumate tekstidega. ${ }^{17}$

\section{Läti rahvalaulude teekond Herderini}

Riia-perioodil koges Herder vahetult lätlaste laulmisi, kuid rahvalaule koguma hakkas ta 1770. aastal. Siiski on viimati öeldu vaid oletus, sest me ei või kindlalt teada, kas siis, kui ta 1769. aasta mai viimastel päevadel Dünamünde (Daugavgrīva) sadamast lahkus, võis tal reisikotis kaasas olla ka läti rahvalaulude üleskirjutusi. Igal juhul oli Herderi lahkumisest möödas enam kui aasta, kui ta 1770. aasta 14. oktoobriga dateeritud kirjas oma pruudile, hilisemale abikaasale Karoline Flachslandile mainis teiste rahvaste laulude kõrval ka lätlaste omi:

Ma võiksin Teile oma kogutud kraami hulgast saata veel hulga muudki laule: araabia eesliajajatelt, itaalia kalameestelt, lumes jahti pidavatelt 
ameerika küttidelt ja ka laplastelt, gröönlastelt ning lätlastelt. ${ }^{18}$ (Herder 1984: 103.)

Leonid Arbusow on välja pakkunud, millised lätikeelsed tekstid võisid olla sel ajal Herderi käsutuses: lätikeelne salmike koos saksakeelse tõlkega Friedrich Christian Weberi päeviku-vormis kirjutatud reisikirjast "Das veränderte Rußland..." (Muutunud Venemaa, vt Weber 1744: 70-71 [1721]) ${ }^{19}$, kaks Philipp Ruhigi (1747) leedu keele grammatikast pärit leedu rahvalaulu (selgub, et esialgu Herder ei eristanud neid läti lauludest) ja Gotthard Friedrich Stenderi (1761) läti keele grammatikast pärit kümme luulenäidet (Arbusow 1953: 151-155). Et selles kogus oleksid olnud juba ka "Kevadlaulus" avaldatud tekstid, on vähetõenäoline, kuid sellist võimalust täielikult välistada ei saa. Herderi esimene rahvalaulude väljaanne "Alte Volkslieder" (Vanad rahvalaulud) trükiti 1774. aastal, kuid seda ei levitatud, ning on võimalik, et Herder oli sunnitud selle hävitama. Ilmselt ei rahuldanud Herderit ka tekstide vähesus, mis võiski kaasa tuua järgnenud tekstide kogumisaktsiooni. Ent kes ja mis põhjusel aitasid Herderit selles ettevõtmises?

Pärast Riiast lahkumist tõusis Herderi autoriteet järsult, seda eriti 1776. aastast, mil temast sai Weimaris ülemsuperintendent. Sellest tulenevalt leidus Liivimaal tuntud kirjamehi ja kirikuõpetajaid, kes pidasid oma auasjaks ja meelepäraseks kohustuseks Herderile meeldida. Samuti oli selleks ajaks juba välja kujunenud püsiv intellektuaalide suhtlusvõrgustik, mille liikmed tundsid huvi kohaliku kultuuri vastu. Baltisaksa intellektuaalid vahetasid raamatuid ning arutlesid nii kirja teel kui ka seltskonnas suheldes lätlaste ja eestlaste kultuuri ning päevakajaliste teemade üle. 18. sajandi teise poole baltisaksa kirjameeste ja kirikuõpetajate tegevust, nagu ka läti kultuurielu kohta andmete kogumist ei ole kuigi palju ja kuigi süvitsi uuritud. ${ }^{20}$ Kuid lähtudes tolleaegsest kirjalikust pärandist ja käsikirjade võrdlevast vaatlusest ilmneb, et näiteks Herderile rahvalaule saatnud Heinrich Baumann (1716-1790) on laule kirja pannud juba enne, kui Herder selle palve esitas. Nimelt märgib Heinrich Baumann ${ }^{21}$ oma päevikusse 1765 . aasta oktoobris (see on enam kui kümme aastat enne Herderile laulude kogumist), et ta "saatis ühe lätlaste vana pulmalaulu" kellelegi, kes seni on jäänud uurijatele tundmatuks (LVVA f 4038 n 2 s 91). Arvatavasti pani ta selle teksti kirja, olles kuulnud seda oma koguduse talupoegadelt. Paar aastat hiljem, 1767. aasta 20. augustil sai ta omakorda kirja (taas uurijatele tundmatult saatjalt), mis sisaldas "mitmeid muistseid lätlaste salme" (Tischer 2011: 146, vt ka LVVA f 4038 n 2 s 91). Võib oletada, et selliseid käsikirju oli ka kirjastajal Christoph Harderil (1747-1818) ja pastor Gustav Bergmannil (1749-1814), kes samuti on Herderile läti rahvalaule kogunud. Gustav Bergmann oli 1776. aastal avaldanud teose "Geschichte 
von Livland, nach Bossuetischer Art entworfen" (Liivimaa ajalugu, kirjutatud Bossuet' stiilis). Lisaks tuleb mainida Johann Jakob Harderit (1734-1775) ja tema artiklit "Untersuchung des Gottesdienstes, der Wissenschaften, Handwerke, Regierungsarten und Sitten der alten Letten, aus ihrer Sprache" (Uurimus vanade lätlaste jumalateenistusest, teadustest, käsitööst, valitsemisviisidest ja tavadest, otsustades nende keele põhjal), mis oli avaldatud perioodilises väljaandes Gelehrte Beyträge zu den Rigischen Anzeigen (Harder 1764). See artikkel sisaldab mitmeid läti mõistatusi ja rahvalaulufragmente. Herder tsiteerib seda artiklit läti rahvalaulude selgitustes (Herder 1990: 294 jj).

Liivimaa rahvaluule kogumise alguseks peetakse 1777. ja 1778. aastat, sest siis hakkasid Herderi palvest innustust saanud kohalikud kirikuõpetajad ja literaadid sihipäraselt üles kirjutama lätlastelt ja eestlastelt kuuldud lugusid. Rahvaluule kogumine Liivimaal on Herderi rahvalaulude kogumisprotsessis unikaalne, sest kogumine toimus autentses keskkonnas, laulud pandi kirja ilma vahendajata, s.o otse jutustajatelt-lauljatelt, ja loomulikult polnud neid lugusid ka veel kuskil avaldatud. Nagu küll ka mõned Liivimaa laulud, pärinesid kogumikus avaldatud teiste rahvaste laulud enamasti varasematest trükiallikatest. Paljud tekstid esindasid aga hoopis tuntud autorite loomingut. Kui Herder võrdleb laplaste laule Ewald Christian von Kleisti "rahvuslikus stiilis" luulega, hüüatab ta:

Siit saate te kena laplaste laulukese, mille eest ma annaks kümme Kleisti jäljendust [...]. Sest too laulis laulu otse käigu pealt [...], aga Kleist jäljendas raamatus äratrükitut. ${ }^{22}$ (Herder 1984: 297.)

Et kujutleda läti rahvalaulude teekonda Weimarisse, kuhu Herderile laule saadeti, tuleks visandada nende inimeste ringkond, kelle poole Herder sellise tol ajal ootamatu palvega võis pöörduda. Nii Ludis Bērziņš, kirjeldades Herderi kogus säilinud läti rahvalaule kui ka Leonid Arbusow ja Arveds Švābe on pakkunud välja, kes võisid olla Herderi kirjasaatjad (Bērziṇš 1933; Arbusow 1953; Švābe 1958). ${ }^{23}$ Mainitud on mitmeid 18. sajandi teise poole Läti, Leedu ja Eesti kultuuriajaloos suuremal või vähemal määral olulisi isikuid. See küsimus jääb arvatavasti igaveseks ammendava vastuseta, sest on võimalik, et tekstide käsikirjad, olgugi et need on konkreetsete inimeste poolt kirja pandud, on maha kirjutatud teiste inimeste märkmetest, mida omakorda pole enam alles või pole veel leitud.

Kokkuvõttes tuleb rõhutada, et rahvalaule pandi kirja juba enne Herderi üleskutset, kuid just tänu selliste omaaegsete kolleegide ja hiljem laiemalt tuntuks saanud tegelaste huvile muutus laulude väärtus baltisakslastest kirjameeste ja kirikuõpetajate silmis. Kuid see ei toimunud ühe hetkega. Oluline on ka märkida, et läti rahvalaulud jõudsid Herderini mitte otse, vaid August Wilhelm Hupeli (1737-1819) vahendusel. 


\section{Läti rahvalaulude saatjad}

Pole teada, et Herder oleks Riia-perioodil jõudnud isiklikult tutvuda Põltsamaal tegutsenud August Wilhelm Hupeliga. Hupeli kirjanduslik tegevus 1770. aastatest alates oli aga Herderile kindlasti tuntud ja Hupeli uurimust "Topographische Nachrichten ..." (Topograafilised teated ..., Hupel 1774-1782) hindas Herder kõrgelt (vrd Jürjo 2004: 201). Hupelil oli väga lai tutvusringkond. Ta oli Liivimaa üks tegusamatest valgustusajastu kirikuõpetajatest ja kirjameestest väljaspool Riiat (vt Jürjo 2004: 9-12, 168-172, 239-242). Tõenäoliselt hävitas Hupel Herderi 1777. aasta septembri lõpus või oktoobri alguses kirjutatud kirja palvega saata rahvalaule. ${ }^{24}$ Küll aga võib Herderi palvest leida märke Hupeli enda kirjadest oma kohalikele kolleegidele. Sealhulgas proovib Hupel Herderit läti laulude hankimisel aidata, pöördudes 1777. aasta 17. oktoobril kahe Riias elava tuttava, Jakob Benjamin Fischeri (1731-1793) ja Johann Friedrich Hartknochi (1740-1789) poole (Jürjo 2004: 398-401). ${ }^{25}$

Johann Friedrich Hartknoch oli kirjastaja, kelle raamatuäri asus ajavahemikus 1765-1771/72 Riias Jauniela (Neugasse) tänavas sõjaväearst Heroldi majas, kus Herder oli oodatud külaline (Taszus 2011: 243-244). Nii on ootuspärane et Riia-perioodist pole tallel ühtegi Herderi ja Hartknochi vahelist kirja - neid lihtsalt polnud vaja kirjutada. Hiljem olid nad tihedas kirjavahetuses. Hartknochi surma järel 1789. aastal võttis äri üle Hartknochi poeg, kellest hiljem sai Herderi tööde väljaandja (ibid.: 389, 393 jj). 1777. aasta 17. oktoobril vahendas Hupel Hartknochile adresseeritud kirjas Herderi palve:

Herder palub minult eesti ja läti rahvalaule; tahan need talle hankida; kas Teie ei saaks mulle üht-teist muretseda, nimelt mõningaid lätlaste laule, näiteks pulmalaule etc., mis poleks aga liiga naiivsed; ühes võimalikult sõnasõnalise täpse tõlkega. Ühel või kahel palun ma värsimõõdu ära märkida ja, kus võimalik, juurde lisada lauluviis tiiskantnootides. Eriti palub ta neid lätikeelseid laule koos tõlkega, mida Ruhig oma grammatikas esitavat. Seda raamatut mul pole. Hankige mulle vähemalt need laulud läti ja saksa keeles ühes värsimõõduga. ${ }^{26}$ (LUAB RRGN Ms 282, m 4: 44 (inv nr 472); vt ka Jürjo 2004: 398-399.)

Samal päeval, 1771. aasta 17. oktoobril kirjutas Hupel soovist saada läti rahvalaule ka Riias elavale loodusuurijale ja apteekrile Jakob Benjamin Fischerile $(1731-1793)^{27}$ :

Nü̈d üks suur palve, vabandage minu jultumust. Oma suure tutvuskonna abil saate Teie minu soovi peatselt täita. Hankige mulle mõned läti rahvalaulud, mida nad oma pidudel, pulmades etc., etc. isekeskis 
laulavad, koos sõnasõnalise tôlkega, kui võimalik, siis vähemalt üks koos tiiskantnootides lauluviisiga ja ühe või 2 silbimõõdu äramärkimisega. Ainult et kirjutada tuleb loetavalt. Usinal praost Baumannil peaks tema kogude hulgas ju mõni läti rahvalaulukogu olema või pastor Bergmannil. Ruhig pidavat oma grammatikas paar läti laulu ära tooma, neid tahaks ma ülakirjeldatud kombel eriti saada. Palun täitke see palve [---] Kui pastorid peaksid selliste laulude saatmist patuks pidama, siis küllap Te leiate teisi, kes seda paljuks ei pea. Mida teravmeelsemad laulud, seda parem; enamik on ju kaunis naiivsed. ${ }^{28}$ (LVVA f 4038, n 2, s 382, lk 80. Vrd Jürjo 2004: 399.)

Nii kirjas Hartknochile kui ka Fischerile mainitakse läti laule, mis sisalduvat Philipp Ruhigi (1675-1749) grammatikas. Ruhig avaldas 1745. aastal leedusaksa-leedu sõnaraamatu ja paar aastat hiljem lisas sellele traktaadi "Betrachtung der littauischen Sprache in ihrem Ursprung, Wesen und Eigenschaften" (Ülevaade leedu keelest, selle päritolust, olemusest ja iseloomulikest joontest). Läti laule seal ei ole (Ruhig 1747). Et Herder tunneb huvi Ruhigi grammatikas olevate lätikeelsete laulude vastu (mida seal ei ole), on seletatav ehk asjaoluga, et Herder, tundmata keelt, ei eristanud neid keeli ei kõnes ega kirjas.

Praeguse seisuga pole teada ühtegi Hartknochi saadetud läti rahvalauluteksti. Ent soovides Herderit tema tegevuses aidata, mainis ta Herderile 1778. aasta 25. veebruari kirjas võimalikku läti laulude kogujana teoloogiakandidaati Nesslerit. Tõenäoliselt on tegemist Cēsisese (Võnnu, sks Wenden) lähedal asunud Rucka (sks Rutzky) mõisast pärit Christian Gotthard Nessleriga, kes 1779. aasta paiku oli kiriku notar Riias. Hartknoch kirjutab:

Järgmise kirjaga saadab Hupel eestlaste laule, aga kust võtame me lätlaste omad? Noh, vana kandidaat Nessler muretseb need, kuid ta on veidi aeglane. ${ }^{29}$ (Düntzer \& Herder 1861: 63.)

Herder tänab oma rahvalaulude väljaandes Hupelit, kuid mitte Hartknochi. Sellest võib järeldada, et Hartknoch ei olnud tekstide saatjate hulgas. Samas Nessleri võimalikku saadetist ei saa välistada seoses artikli alguses mainitud "Kevadlaulu" alajaotuses avaldatud tekstidega, mille originaale ei ole leitud. Samas võis üks nende tekstide saatjatest olla ka leedu rahvalaulude kirjapanija J. G. Kreutzfeld. 1779. aasta 2. jaanuaril palus Herder Hamannil tervitada Kreutzfeldi, "kellele olen isiklikult tänu võlgu Lettica eest" (Arbusow 1953: 165). ${ }^{30}$ Siiski on see hetkel ainuke teadaolev puutepunkt Kreutzfeldi võimalikust seotusest läti rahvalaulude kogumisega. Lõpuks pole ka välistatud, et Herderile lähetas "Kevadlaulu" aluseks olevad tekstid Hupel. Nimelt on Herder Hartknochi vahendusel tänanud Hupelit saadetud laulude eest kirjas, mis on 
dateeritud 1778. aasta 4. oktoobriga - see on aasta pärast rahvalaulude kogumise aktsiooni algust ning pool aastat pärast laulude kättesaamist. Samas ei saa välistada, et Herderi tänu hilines ajapuuduse ja väsimuse tõttu ning 4. oktoobril läkitatud kirjas üritas ta lihtsalt vana võlga tasuda.

Fischer, kellele Hupel laulude kogumise asjus samuti kirjutas, eeldades et "[u] sinal praost Baumannil peaks tema kogude hulgas ju mõni läti rahvalaulukogu olema või pastor Bergmannil”, läkitaski palve edasi. Ja juba 1777. aasta 31. oktoobril saatis praost Heinrich Baumann Cēsisest (Võnnust) Fischerile rahvalaulutekste, mis on säilinud tänapäevani. Baumanni kirjad Fischerile on huvitavad mitte üksnes sellepärast, et need tõendavad rahvalaulude edasisaatmist, vaid ka sellest aspektist, et need näitavad nii Hupeli asjatundlikkust (kellelt võiks rahvalaulude kirjapanekuid saada) kui ka annavad aimu toonaste kirikuõpetajate suhtumisest rahvaluulesse. Ühtlasi dokumenteerivad need kirjad kirikuõpetajate ja kirjameeste huvi ning positiivse suhtumise tärkamist läti pärimuskultuuri. Baumann kirjutab 1777. aasta 31. oktoobril Fischerile:

Südamesõber, siin saadan Teile mõned lätlaste laulud. Uskuge mind, kallis sõber, et neist luuletustest pole varem midagi kuulda olnud. ${ }^{31}$ (LVVA f 4038 n 2 s 304.)

Kirjadest selgub, et Baumann läkitas Fischerile tekste vähemalt kahel korral. Herderi läti rahvalaulude käsikirjalises kogus leidub tõepoolest kaks Baumanni saadetist (Herder Nachlass XIV: 50, 53.1). Herderi arhiivis on ka Fischeri enda käega kirjutatud läti rahvalaulude tekste. Võib oletada, et Fischer kirjutas nii Baumanni kui Bergmanni saadetud tekstid oma käega ümber, veendumaks, et need on Herderi jaoks loetavad (nagu Hupel oma kirjas Fischerile toonitas: "Ainult et kirjutada tuleb loetavalt"). Fischeri palvele vastas ka Johann Christoph Brotze. Kõnesolev Brotze kiri on dateerimata, ning selle võib leida taas Herderi isikuarhiivist Berliini Riigiraamatukogus. On tõenäoline, et Brotze saatis selle kirja Fischerile nimelt eelkirjeldatud Liivimaa rahvalaulude kogumise aktsiooni ajal 1777. aasta lõpus või 1778. aasta alguses. Brotze kirjutab: "Härra Ehrebaumil [isik pole kindlaks tehtud, nimi raskesti loetav - B. P.] ei ole läti rahvalaule. Selle laulu kirjutan maha Weberi Verändertes Rußland'ist." (Herder Nachlass XIV: 49). ${ }^{32}$ Brotze otsuses saata laulukogujale näiteid juba avaldatud tekstidest, pole midagi ebaharilikku või ootamatut, sest Herder kasutas rahvaste laulude otsinguks reisikirjades või mujal populaarteaduslikus kirjanduses avaldatud kohalikku luulet. Siiski tundub, et Brotze oli ainuke, kes saatis Herderile juba publitseeritud ja võimalik, et kohaliku saksa kogukonna seas laialt levinud teksti. 


\section{Rahvalaulu mõiste ja laulude kogumisviis 18. sajandi lõpul}

On tähelepanuväärne, et Brotze kasutab eeltsiteeritud kirjas Fischerile mõistet rahvalaul (Volkslied). Heinrich Baumanni esimestes kirjades sellist mõistet ei leidu. See tõestab, et Brotze kuulus koos Hupeli ja Hartknochiga Liivimaa ühiskonna- ja kultuuriteemasid jälgivate inimeste hulka. Kuid Herderi üleskutse oli ärgitanud ka Liivimaa kirikuõpetaid kaasa mõtlema. 1778. aasta 13. märtsil kirjas Fischerile kasutab Baumann juba rahvalaulu mõistet: "Rääkige mulle, armas sõber!, mida tahab härra ülemsuperintendent Herder - tema kui omaaegse Liivimaa õpetlase igati õnnestunud portree asub minu livonica kogus - teha meie läti rahvalauludega?" (LVVA f 4038 n 2 s 304). ${ }^{33}$ Nagu näha, on ka Heinrich Baumannini - võimalik, et Herderi üleskutse mõjul - jõudnud mõiste rahvalaul, ja ka tema on hakanud seda kasutama. See väike märkus viitab Herderi ideede levikule klassikalisest Weimarist kaugele Liivimaale.

Herderi mõttekaaslased kasutasid mõistet rahvalaul üldiselt enesestmõistetavana. Kirikuõpetajad, kellel oli vahetu side kohalike elanikega, ei tundnud veel seda sõna ja seetõttu kasutasid nad sel ajal paremini tuntud mõisteid nagu talupoegade laulud või lätlaste poeesia. Gotthard Friedrich Stenderi 1761. aastal ilmunud grammatikas on mõisted talupoegade laulud ja ajaloolised laulud (Stender 1761: 152). Alles 1783. aasta grammatika väljaandesse ilmub mõiste rahvuslikud laulud (sks nationale Lieder, läti nacionālās dziesmas), mis seob need tekstid mitte sotsiaalse klassi, vaid etnilise kogukonnaga.

Laulude kogumisprotsessi lähemalt vaadeldes tuleb esile selle kolmeastmelisus. Herder kui mitmeid rahvusi ühendava suure idee looja andis baltisaksa vaimsele eliidile ülesande hankida rahvalaule. Kohalik eliit (Hupel, Hartknoch, Fischer) andis selle ülesande omakorda rahva valgustamisega tegelevatele pastoritele või teistele, kellel oli lätlaste ja eestlastega otsene side, erinevalt saksa eliidist, kes oli neist nii sotsiaalselt kui ka etniliselt kaugel. Kirjeldatud kolmeastmelisus osutus efektiivseks: tekitab imetlust, kui kiiresti (vaid kahe kuu jooksul) jõudis Herderini vähemalt 80 teksti. 21. veebruaril 1778. aastal andis Hupel Fischerile teada, et kirjad on Herderile edasi saadetud (LVVA f 4038 s 2 n 382). Sama aasta 11. aprillil kirjutas Herder Heinrich Christian Boiele, et ta "sai eile korraliku paki eestlaste ja lätlaste lauludega" (Herder 1986: 45). Ilmselt on siin juttu Hupeli saadetisest. Sellest võib järeldada, et Hupeli kaastöö nii enda kirja pandud eesti laulude kui ka Fischeri vahendusel saadud läti lauludega oli Herderi käsutuses 1778. aasta aprilli alguses. Tõenäoliselt on eelmainitud kirjas juttu lauludest, mis praegu asuvad Herderi isikuarhiivis: 
Hupeli läti ja eesti tekstide juhtkirjad on sarnased, mis muudavad sellise oletuse vägagi usutavaks (Herder Nachlass XIV: 48 (eesti), 49, 50, 51, 52, 53 (läti)). Igal juhul sai Herder 1778. aasta kevadel alustada laulude väljavalimisega, et need avaldada. Pole teada, et Herder oleks palunud mõnda lisaselgitust läti tekstide kohta, mistõttu võib eeldada, et saadud tekstide sõnasõnalised tõlked olid piisavad, et neid töödelda ja avaldada saksakeelse luulena.

\section{Läti rahvalaulutekstid Herderi isikuarhiivis}

Herderile saadetud läti rahvalaulude originaaltekstid on Herderi isikuarhiivis XIV toimikus mappides number $49,50,51,52,53 .{ }^{34}$ Sama toimiku mappides nr 28, 29 ja 43 on läti tekstide saksakeelsed tõlked ilma lätikeelsete tekstideta. Mapis nr 49 on Johann Christoph Brotze Jakob Benjamin Fischerile adresseeritud kirja fragment, mis sisaldab Weberi reisikirjast pärit teksti lätikeelset originaali ja selle saksakeelset tõlget. Läti tekstide tuuma moodustavad mapid nr 50-53, kusjuures mapp nr 53 on jaotatud kahte ossa (53.1 ja 53.2), kuna see sisaldab kahte erineva käekirjaga kirjutatud kogu. Neid tekste on avaldanud Ludis Bērziṇš (1933; 2007) ja Leonid Arbusow (1953).

Herderi arhiivi dokumentide ning Läti Rahvusraamatukogus, Läti Ülikooli Akadeemilises Raamatukogus ja Läti Rahvusarhiivis leiduvate tekstide autorite käekirju võrreldes õnnestus tuvastada neli laulude üleskirjutajat. Mapis nr 50 ja 53.1 on Heinrich Baumanni käega kirjutatud tekstid. Säilikus nr 51 on Jakob Benjamin Fischeri kirjutatud käsikiri: selles on nii mapis 50 (Heinrich Baumanni) kui ka 52 (Gustav Bergmanni) saadetud tekstid, lisaks mõned originaaltekstid, mis ei kuulu ei Bergmannile ega Baumannile. Mapis 53.2 on August Wilhelm Hupeli poolt kirja pandu.

Tuleb rõhutada, et Herderi uurimustes on pakutud välja mitmeid rahvalaulutekstide saatjaid (vt ülevaadet uurimustest Paškevica 2003). Pärast käekirjade tuvastamist on selgunud, et kõik laulude saatjad on seotud eelkirjeldatud kirjavahetustega, mis tõukusid Herderi üleskutsest. 

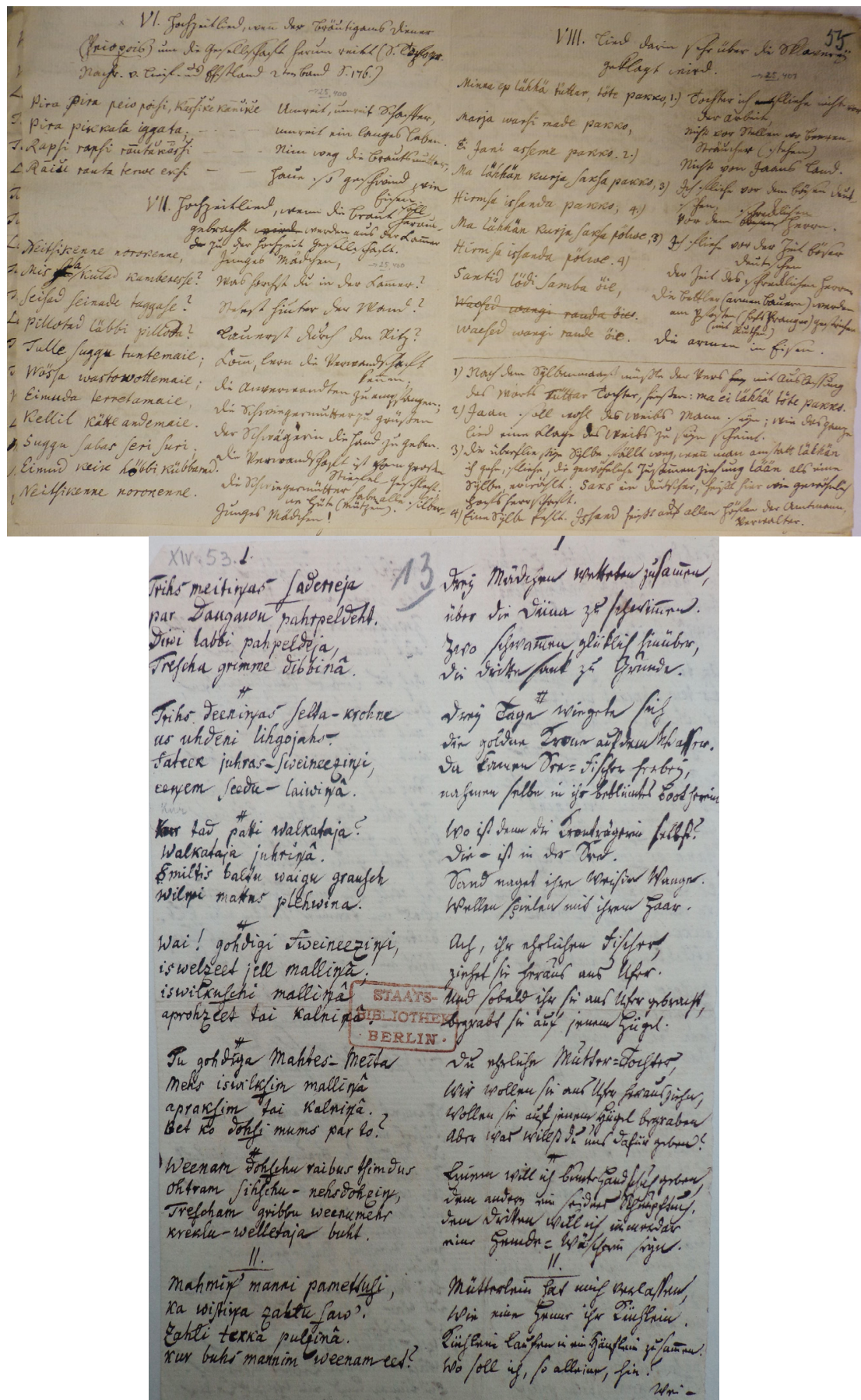

A. W. Hupeli eesti- ja lätikeelne käsikiri (Herders Nachlass XIV: 49, 53.2). Herderi erakogu esimesel leheküljel on Hupeli käekirjaga märgitud, et saksa tekstid on kirjutatud gooti kirjas, aga originaaltekstid ladina tähtedega (Herder Nachlass XIV: 50). Selline eristus saksa ja teistes keeltes kirjutamiseks oli tollel ajal tavaline. 


\section{Kokkuvõte}

Herderi ja ka Baltimaade valgustusaja uurimises on üllatuseks August Wilhelm Hupeli nii suur roll läti tekstide kogumisel. See fakt ärgitab taas kord küsima, kas Hupel mitte ei osanud läti keelt, ning mil määral oli ta seotud läti kultuurielus toimuvaga. Hupel oli tegutsenud Riias ja osalenud hiljem Põltsamaal Peter Ernst Wilde perioodilise väljaande Der Landarzt juures, avaldades sellest eestikeelse versiooni pealkirjaga "Lühhike öppetus ..." ${ }^{35}$ Võib küsida, kas ta tegi mingil määral koostööd ka praost Jakob Langega, kes sama ajakirja läti keelde tõlkis ja avaldas pealkirja all Latweeschu Ahrste. ${ }^{36}$ August Wilhelm Hupel täiendas ka Jakob Benjamin Fischeri loodusteaduslikku kirjeldust, lisades sellele läti- ja eestikeelseid taime- ja loomanimesid (Jürjo 2004: 178). Kuna Hupel võttis innukalt osa ka lätikeelsete tekstide kogumisest, tuleks senisest enam tähelepanu pöörata ka tema rollile läti kultuuriloos.

Kokkuvõttes võib järeldada, et Herderi käsutuses olev läti rahvalaulude kogu oli mahukam kui see, mis tänaseks alles on jäänud. Sellise mahuka tekstikogu koondumise Herderi kätte tagas Liivimaa intellektuaalide aktiivne suhtlusvõrgustik, mille uurimine pakub aina uut teavet Euroopa valgustusajastu ideede ajaloo ja eriti Baltimaade kultuuriloo kohta.

\section{Kommentaarid}

1 Toim: Artikkel on tõlgitud läti keelest eesti keelde Wiedemanni Tõlkebüroos. Saksakeelsed tekstid toimetas Reet Bender.

Tänan Berliini Riigiraamatukogu Preisi kultuuripärandi käsikirjade osakonda loa eest avaldada käsikirja pilte; Berliini Humboldti Ülikooli teadlast Kaspar Rennerit, kes minu palvel otsis välja, digitaliseeris ja saatis mulle läti rahvalaulude tekstid; Läti Ülikooli Akadeemilise Raamatukogu käsikirjade ja haruldaste raamatute osakonna juhatajat Aija Taimin̦at käsikirjade määratlemisel tehtud koostöö eest.

2 Originaalis: Alle Welt und Sprache, insonderheit der älteste, graue Orient liefert von diesem Ursprunge Spuren die Menge, wenn es solche vorzuführen und aufzuzählen Not wäre.

3 Toim: nii kõnesolevad üksteist läti kui seitse eesti teksti on leitavad kogumiku II osa 2. raamatust: vt pulmalaulud (1. "Einige Hochzeitlieder") ja pärisorjuse teemaline laul (2. "Klage über die Tyrannen der Leibeignen"), lisaks on sissejuhatavas osas "Nachrichten..." avaldatud Chr. Kelchi kroonikas trükitud nn Jörru-laul. Läti tekstid on vastavalt: 7. "Fragmente Lettischer Lieder" (Läti laulude fragmendid), 8. "Frühlingslied" (Kevadlaul) (vt Volkslieder 1778/1779: http://www.zeno.org/Literatur/M/ Herder,+Johann+Gottfried/Liedsammlung/Volkslieder). Laulukogu hilisemates trükkides, pealkirjaga "Stimmen der Völker in Liedern" (Rahvaste hääled lauludes) on eesti laulud alajaotuses 4-8 (mõned pulmalaulud, Jörru-laul, üks vanapoisi- ja üks sõjalaul ("Der Hagestolze" ja "Lied vom Kriege") ning läti laulud on vastavalt alajaotuses 9 ("Kevadlaul”) ja 10 ("Läti laulude fragmendid") (Herder 1880: 26-38). Eesti 
laulude originaalid, saksakeelsed tõlked ja Herderi töötlused on avaldatud Õpetatud Eesti Seltsi toimetistes (ÕES XVI, 1896: 241-267, http://hdl.handle.net/10062/19354).

4 Tekstide arv on suhteline, sõltudes teksti piiride määratlemisest: tihti on värsid kirjutatud samale reale, siis jällegi jaotatud mitmele reale.

5 Herderi rahvalaulde väljaandes "Volkslieder" on kaks osa (I ja II). I osa koosneb kolmest raamatust, iga raamat omakorda 24 laulust ( 3 x 24). Kogumiku II osa koosneb samuti kolmest raamatust ning igas raamatus on omakorda 30 laulu ( $3 \times 30)$.

6 "Loomishieroglüüf” kohta vt ka Sauder 2005.

7 Originaalis: Diese Schöpfungshieroglyphe in der von Herder beschriebenen siebenstufigen und triadischen Anordnung ist "höchstes und simpelstes Ideal der Dichtkunst" (SW 6, S. 322) und muß sich als Prinzip der Entfaltung natürlich da anbieten, wo es um die schöpferische Bewältigung von Grundsituationen wie Liebe, Tod, Angst, Grauen, Leidenschaft, Herrschaft etc. durch Menschen überhaupt geht - denn die konsequente Durchmischung der Lieder zeigt, daß hier nicht nationale oder ethnologische Besonderheiten, sondern anthropologische Gemeinsamkeiten Zusammenhänge stiften, wenn überhaupt Zusammenhänge über die Kleingruppen hinaus bestehen.

8 Originaalis: Wenn Frau Sappho und ein littauisches Mädchen die Liebe auf gleiche Art singen, wahrlich müssen die Regeln ihres Gesanges wahr sein, sie sind Noten der Liebe und reichen bis ans Ende der Erde.

9 Originaalis: Die nationale und die anthropologische Tendenz sollten in der Stimme einer idealen Menschheit zusammenklingen.

${ }^{10}$ Originaalis: Stimme des Volks, der zerstreuten Menschheit.

${ }^{11}$ Originaalis: Jeder sprach aus dem Munde seiner Väter: er sahe nach der Welt, die um ihn war, er machte sich Aufschlüsse, von Dingen, die ihm als merkwürdigsten vorlagen, und nach der Art, wie sie seinem Klima, seiner Nation, seiner bisherigen Leitung nach am besten konnten erkläret werden: er schloß nach seinem Interesse und nach der Denkart, Sprache und Sitten seines Volks.

12 Originaalis: Ist Norden oder Süden, Morgen oder Abend die Vagina hominum gewesen? Welches der Ursprung des Menschengeschlechts, der Erfindungen und Künste und Religionen?

${ }^{13}$ Originaalis: Im Ursprünglichen ist das Göttliche anzuschauen; Volk als Idealbegriff ist eine Ursprungskategorie, ein "Volkslied" in diesem Sinne ist eine (als Lied wiederum ursprüngliche) Erscheinungsform des Göttlichen, in der es anschaubar, als Inhalt hörbar, als Tonart vernehmbar wird, [...].

${ }^{14}$ Originaalis: [...] aus meinem ganzen Zeitalter weg, dahinaus zu versetzen, wo diese Urkunden offenbart, wo sie aus dem Munde des Volks gesammelt wurden, und lebten.

15 Jutt on luuletusest "Der Eistanz" (Jäätants). "Rahvalaulude" (Volkslieder) II osa 3. raamatus on kirjutatud, et see on saksa laul, kuid autorit (nagu ka paljude teiste tekstide korral) ei ole mainitud. Vt nt Zeno.org: Volltextbibliothek: http://www.zeno. org/Literatur/M/Herder,+Johann+Gottfried/Liedsammlung/Volkslieder/Zweiter+Theil/ Drittes+Buch/26.+Der+Eistanz.

${ }^{16}$ Hupeli saadetud originaaltekstis on laulu pealkiri veidi erinevalt sõnastatud: "Lied darin sehr über die Sklaverey geklagt wird” (Laul, milles väga orjuse üle kaevatakse). Herder on seda sõnastust muutnud ilmselt parema kõla eesmärgil, kasutades aga seejuures laulude sõnumi tähendust rõhutavat sõna "türann". (Vt Herder Nachlass XIV: 48, 55.) Toim: Indrek Jürjo hinnangul ei saanud Hupelil selle laulu suhtes sotsiaalset 
tõrget veel olla, küll aga ei lubanud tsensuur mitmeid selleteemalisi laule avaldada kolmveerand sajandit hiljem A. H. Neusi eesti rahvalaulude kogumikus (Jürjo 2004: 403).

${ }^{17}$ 1761. aastal välja antud Stenderi grammatika lõpus "Anhang einiger Lettischen Gedichte" (Lisaks mõned läti luuletused) on avaldatud Stenderi luuletõlked ja originaalluulet (Stender 1761: 200-220), kuid läti rahvalaule seal ei ole. Rahvalaule leiab (talurahva laulude) näidetena grammatika V osast "Von der Poësie" (Luulest) ja ka muudes keele sõnavara teemadele pühendatud osadest (Stender 1761: 152-164).

${ }^{18}$ Originaalis: Nun könnte ich Ihnen noch aus meinem Kram einen guten Teil andere hinzu setzen: arabische von Eseltreibern, Italienische von Fischern, Amerikanische aus der Schneejagd, item Lapp-, Grönländische und Lettische.

${ }^{19}$ Rahvalaulude kogumise käigus sai Herder selle Weberi reisikirjast pärit tsitaadi veel kord: selle saatjaks oli Fischeri ja Hupeli kaudu Johann Christoph Brotze (Bērzin̄š 1933).

${ }^{20}$ Siin tuleb märkida Indrek Jürjo monograafiat August Wilhelm Hupeli kohta (Jürjo 2004; saksa keeles 2006), Arveds Švābe tööd Gustav Bergmanni kohta (Švābe 1958), Aija Taimiṇa väitekirja Johann Christoph Brotzest (Taimiṇa 2013); Zigrīda Frīde uurimust Gotthard Friedrich Stenderist (Frīde 2003). Muidugi on olemas ka väiksemaid uurimusi.

${ }^{21}$ Seni kõige ulatuslikumat uurimust Heinrich Baumanni tegevuse kohta vt Tischer 2011.

${ }^{22}$ Originaalis: Hier bekommen Sie ein hübsches Lappländisches Liedchen, wofür ich zehn Kleistische Nachahmungen [...] geben möchte. Denn jener sang das Lied eben aus dem Fluge [...]; Kleist aber ahmte aus dem Buche nach.

${ }^{23} \mathrm{Vt}$ andmeid viidatud teaduskirjanduses esitatud potentsiaalsete Herderile rahvalaulude saatjate kohta Paškevica 2003.

${ }^{24}$ Oma materjalide tahtlik hävitamine toimus korduvalt (nt 18. sajandi lõpul,19. sajandi alguses tugevnenud tsensuuri ja valgustusideede vastaste repressioonide tõttu). Selline tahe oli avaldatud ka A. W. Hupeli testamendis (vt Jürjo 2004: 29, 103 jj).

${ }^{25}$ Hupel vahendas Herderile kokku 79 läti ja 8 eesti laulu, ent seda pigem soovist aidata "kirjanduslikku kuulsust" Herderit kui huvist rahvalaulude ja nende publitseerimise vastu (Jürjo 2004: 400). Indrek Jürjo on ühtlasi maininud Hartknochi palvet Herderile, et too saadaks Hupelile teate laulude kättesaamise kohta või tänuavalduse selle töö eest (ibid.). Kas Herder sellise kirja Hupelile saatis, ei ole teada.

${ }^{26}$ Originaalis: Herder bittet mich um estn. und lettische Volkslieder; ich will sie ihm schaffen; aber könnten Sie mir nicht einen Beytrag schaffen, nemlich etliche lettische Lieder bey der letten Hochzeitsfesten etc. die nicht ganz einfältig sind, nebst einer wörtlich treuen Uebersetzung, eins oder 2 bitte ich mit dem Silbenmaa $\beta$ zu bezeichnen, und wo möglich die Sangweise in Diskantnoten, beyzufügen. Sonderlich bittet er die Lieder im lettischen nebst der Uebersetzung welche Ruhig in seiner Grammatik anführen soll. Das buch habe ich nicht. Schaffen Sie mir wenigstens diese Lieder lettisch und deutsch nebst Silbenmaaß.

27 Jakob Benjamin Fischer oli Riia apteeker, loodusuurija, orbudekodu raamatupidaja (vt nt Jürjo 2004: 177 jj). Hupel avaldas oma "Topograafiliste teadete" teises köites Fischeri loodusteadusliku Liivimaa kirjelduse, 1778. aastal ilmus see Fischeri kuulsaim töö ja ajalooliselt esimene loodusteaduslik Liivimaa kirjeldus eraldi raamatuna (Fischer 1778). Fischer näitas üles huvi ka rahvalaulude vastu. Käsikirjalist uurimust laulikute, luule- ja laulukogumike kohta on mainitud teatmeteoses "Baltisches 
Biographisches Lexicon", kuid puudub info selle kohta, kas see käsikiri on säilinud [BBLd 2016: 218].

${ }^{28}$ A. W. Hupel kasutab läti rahvalauludest rääkides sama väljendit, mida Stender 1761. aasta grammatikas - einfältig: naiivne, lihtne, lihtsameelne (Stender 1761: 153). Originaalis: Nun eine große Bitte, verzeihen Sie meine Dreistigkeit. Durch Ihre große Bekanntschaft können Sie meinen Wunsch bald erfüllen. Verschaffen Sie mir etliche Volkslieder der Letten, die sie bei ihren Festen, Hochzeiten etc. etc. unter sich singen, mit einer wörtlichen Übersetzung, wo möglich wenigstens eins mit der Sangweise in Diskantnoten, und eins oder 2 mit Bezeichnung des Silbenmaaßes über den ersten Zeilen. Nur deutlich geschrieben. Sollte der fleißige Propst Baumann unter seinen Sammlungen, wohl eine lettische Volksliedersammlung haben, oder der Past. Bergmann. Ruhig soll in seiner Grammatik ein paar lett. Lieder anführen, da wollte ich sonderlich gern auf angezeigte Arb. Gewähren Sie mir diese Bitte. [...]. I Wenn Pastores es für Sünde halten, solche Lieder mitzuteilen; so finden Sie wohl andere die dazu geneigt sind. Je witziger die Lieder, desto besser; die meisten sind doch einfältig.

${ }^{29}$ Originaalis: Hupel wird nächste Post Volkslieder schicken, das sind Estnische; aber wo kriege ich Lettische? Nun, der alte Candidat Nessler will dafür sorgen, aber der ist langsam.

${ }^{30}$ Tsiteeritud Arbusowi järgi: dem ich für die Lettica eigenhändig hätte danken sollen.

${ }^{31}$ Originaalis: Hier folgen, Herzensfreund, einige lettische Poesien. Glauben Sie wohl, liebster Freund! Daß von solchen Poesien niemals je etwas gehöret.

32 Originaalis: Herr Ehrebaum [perekonnanimi loetamatu - B. P.] hat keine lettischen Volkslieder. Aus Webers Verändertem Rußland schreibe ich dieses Volkslied ab.

${ }^{33}$ Originaalis: Melden sie mir doch, liebster Freund! was will Herr Generalsuperintendent Herder - sein wohlgetroffenes Bildnis als eines ehemaligen liefl. Gelehrten liegt unter meinen livonicis - mit unsern lettischen Volksliedern machen.

${ }^{34}$ Berliini Riigiraamatukogu Preisi kultuuripärandi käsikirjade osakonna lahkel loal ja tänu Berliini uurijale Kaspar Rennerile saab neid käsikirju vaadata Läti Ülikooli folkloorikogu kodulehel www.gramantas.lv (http://garamantas.lv/ee/collection/2321/ Johann-Gottfried-von-Herders-Collection-of-Latvian-Folksongs).

${ }^{35}$ Vt Hupeli ja Riia seoseid lähemalt Jürjo 2004: 40-42.

${ }^{36}$ Selle viite eest tänan Läti rahvusraamatukogu (Latvijas Nacionālā Bibliotēka) direktorit Andris Vilksi.

\section{Allikad}

Herder Nachlass XIV: 49-53 - Herderi isikuarhiiv, Berliini Riigiraamatukogu Preisi kultuuripärandi käsikirjade osakond (Staatsbibliothek zu Berlin Preußischer Kulturbesitz).

LUAB RRGN - Läti ülikooli akadeemiline raamatukogu, käsikirjade ja haruldaste raamatute osakond, Riia (Latvijas Universitātes Akadēmiskā bibliotēka, rokraksti un reto grāmatu nodal̦a).

LVVA - Läti Riiklik Ajaloo Arhiiv, Riia (Latvijas Valsts Vēstures Archīvs). 


\section{Kirjandus}

Arbusow, Leonid 1953. Herder und die Begründung der Volksliedforschung im deutschbaltischen Osten. Keyser, Erich (toim). Im Geiste Herders. Gesammelte Aufsätze zum 150. Todestage J. G. Herders. Kitzingen/M.: Holzner 1953 (= Marburger Ostforschungen 1), lk 129-256.

BBLd 2016. Baltisches Biographisches Lexikon digital. Digitalisierungsprojekt der Baltischen Historischen Komission (http://bbl-digital.de/ - 17. oktoober 2016).

Bergmann, Gustav 1776. Geschichte von Livland, nach Bossuetischer Art entworfen. Leipzig: Schwickert (http://www.digar.ee/arhiiv/nlib-digar:46315 - 17. oktoober 2016).

Bērziñ̌̌, Ludis 1933. Atraktā tautas dzeja [Väljakaevatud rahvaluule]. Filologu biedrības raksti [Filoloogide Ühing] 13, lk 114-151.

Bērzin̄š, Ludis 2007. Greznas dziesmas [Uhked laulud]. LU Literatūras, folkloras un māksalas institūts. Folkloras krātuve [Läti Ülikooli kirjanduse, folkloori ja kunsti instituut. Folkloorivaramu]. Riia: Zinātne.

Bultmann, Christoph 2005. Bewunderung oder Entzauberung? Johann Gottfried Herders Blick auf Mose. Keßler, Martin \& Leppin, Volker (toim). Johann Gottfried Herder: Aspekte seines Lebenswerkes. Arbeiten zur Kirchengeschichte 92. Sarja rajanud Karl Holle, Hans Lietzmann, toim Christian Albrecht, Christoph Markschies. Berlin, New York: Walter de Gruyter, lk 15-28.

Düntzer, Heinrich \& von Herder, Ferdinand Gottfried (toim) 1861. Von und an Herder: ungedruckte Briefe aus Herders Nachla $\beta$ II. Leipzig: Dyk'sche Buchhandlung.

Fischer, Jakob Benjamin 1778. Versuch einer Naturgeschichte von Livland. Leipzig: Johann Gottlob Immanuel Breitkopf(https://books.google.ee/books?id=q2MOAAAAQAAJ\&hl=en 18. oktoober 2016).

Frīde, Zigrīda 2003. Latvis. Gothards Frīdrihs Stenders. Riia: Zinātne.

Hamann, Johann Georg 1950. Aesthetica in nuce. Eine Rhapsodie in Kabbalistischer Prose. J. G. Hamann. SW Nadler II. Wien: Thomas-Morus-Presse im Herder-Verlag, lk 195-217.

Harder, Johann Jakob 1764. Untersuchung des Gottesdienstes, der Wissenschaften, Handwerke, Regierungsarten und Sitten der alten Letten, aus ihrer Sprache. Gelehrte Beyträge zu den Rigischen Anzeigen aufs Jahr 1764. Stücke II, V, VII, XII.

Herder, Johann Gottfried 1880. Stimmen der Völker in Liedern. Leipzig: Philipp Reclam jun.

Herder, Johann Gottfried 1899. Sämtliche Werke 32. Suphan, Bernhard (toim). Berliin: Weidmann.

Herder, Johann Gottfried 1909. Sämtliche Werke 14. Suphan, Bernhard (toim). Berliin: Weidmann.

Herder, Johann Gottfried 1984. Briefe. Gesamtausgabe 1763-1803 I. Weimar: H. Böhlaus Nachfolger. 
Herder, Johann Gottfried 1986. Briefe. Gesamtausgabe 1763-1803, I. Weimar: H. Böhlaus Nachfolger.

Herder, Johann Gottfried 1990. Werke in zehn Bänden III. Bollacher, Martin \& Brumack, Jürgen et al. (toim). Frankfurt am Main: Deutscher Klassiker Verlag.

Herder, Johann Gottfried 1993. Über die ersten Urkunden des menschlichen Geschlechts. Einige Anmerkungen. Smend, Rudolf (toim). Schriften zum Alten Testament. Hamburger Klopstock-Ausgabe (HKA) 5. Frankfurt am Main: Walter de Gruyter, lk 9-178.

Herder, Johann Gottfried 1994. Werke in zehn Bänden IX /2. Bultmann, Christoph \& Zippert, Thomas (toim). Frankfurt am Main: Deutscher Klassiker Verlag.

Hupel, August Wilhelm 1774-1782. Topographische Nachrichten von Lief- und Ehstland. Riia: Johann Friedrich Hartknoch.

Jürjo, Indrek 2004. Liivimaa valgustaja August Wilhelm Hupel 1737-1819. Tallinn: Riigiarhiiv = Aufklärung im Baltikum. Leben und Werk des livländischen Gelehrten August Wilhelm Hupel (1737-1819). Quellen und Studien zur baltischen Geschichte 19. Köln: Böhlau Verlag 2006.

Paškevica, Beata 2003. Die Sammlung von Volksliedern im lettischen Livland. Herders Helfer in den Jahren 1777 und 1778. Garber, Klaus \& Klöker, Martin (toim). Kulturgeschichte der baltischen Länder in der Frühen Neuzeit. Frühe Neuzeit 87. Tübingen: Max Niemeyer Verlag, lk 229-243.

Paškevica, Beata 2008. Alunāna dziesmiṇas un Barona dainas - Herdera tautasdziesmu koncepcijas divas izpausmes [Alunani laulukesed ja Baroni lood - Herderi rahvalaulude kontseptsiooni kaks väljendust]. LU raksti. Literatūrzinātne, folkloristika, māksla 731 [Läti Ülikooli artiklid. Kirjandusteadus, folkloristika, kunst 731]. Riia: Läti Ülikool, lk 167-171 (http://www.lu.lv/materiali/apgads/raksti/731.pdf - 19. oktoober 2016).

Ruhig, Philipp 1747. Littauisch-Deutsches und Deutsch-Littauisches Lexicon: nebst einer historischen Betrachtung der Littauischen Sprache wie auch einer gründlichen und erweiterten Grammatick. Königsberg: J. H. Hartung.

Sauder, Gerhard 2005. Altes Testament - neue Literatur der siebziger Jahre. Keßler, Martin \& Leppin, Volker (toim). Johann Gottfried Herder: Aspekte seines Lebenswerkes. Arbeiten zur Kirchengeschichte 92. Berlin \& New York: Walter de Gruyter, lk 29-45.

Stavenhagen, Kurt 1922. Herder in Riga. Rede, gehalten zum Festaktus des HerderInstitutes am 4. September 1922. Riga: G. Löffler.

Stender, Gotthard Friedrich 1761. Neue vollständigere Lettische Grammatik, Nebst einem hinlänglichen Lexico, wie auch einigen Gedichten / verfasset von Gotthard Friedrich Stender. Braunschweig: Gedruckt im Fürstl. großen Waisenhause.

Šešplaukis, Alfonsas 1962. Herder und die Dainos. Commentationes Balticae. Jahrbuch des Baltischen Forschungsinstituts VIII/IX, 4. Bonn: Baltisches Forschungsinstitut, lk 311-357.

Švābe, Arveds 1958. Kāda mācītāja dzīve [Ühe kirikuõpetaja elu]. Stockholm: Daugava. 
Taimiņa, Aija 2013. Johana Kristofa Broces (Brotze, 1742-1823) dzīvesgājums un viña rokrakstu kolekcija LU Akadēmiskajā bibliotēka [J. Ch. Brotze elulugu ja Läti ülikooli akadeemilises raamatukogus leiduvad käsikirjad]. Riia: Latvijas Universitāte.

Taszus, Claudia 2011. Die Fürstlich privilegierte Hofbuchdruckerei Rudolstadt (17721824). Ihre Beziehung zum Verlag Johann Friedrich Hartknoch d.J. und ihre Stellung im literarischen Deutschland 1. Eutin: Lumpeter \& Lasel.

Tischer, Anuschka 2011. Der Sammler als Aufklärer: Das Leben und Wirken Heinrich Baumanns (1716-1790). Kronauer, Ulrich (toim). Aufklärer im Baltikum. Europäischer Kontext und regionale Besonderheiten. Heidelberg: Universitätsverlag Winter, lk 143-163.

Volkslieder 1778/79 = Herder, Johann Gottfried. Volkslieder. Erster Theil. Leipzig, in der Weygandschen Buchhandlung 1778; Volkslieder. Nebst untermischten andern Stücken. Zweyter Theil. Leipzig, in der Weygandschen Buchhandlung 1779 (http://www.zeno.org/ Literatur/M/Herder,+Johann+Gottfried/Liedsammlung/Volkslieder - 19. oktoober 2016).

Weber, Friedrich Christian 1744 [1721]. Das veränderte Rußland in welchem die jetzige Verfassung des Geist und weltlichen Regiments der Kriegs-Staat zu Lande und zu Wasser. Franckfurth, Leipzig: Nicolai Försters und Sohnes seel. Erben.

ÕES XVI 1896 = Verhandlungen der gelehrten Estnischen Gesellschaft 16. Tartu [Dorpat]: C. Mattiesen (http://hdl.handle.net/10062/19354 - 19. oktoober 2016).

\section{Summary}

\section{Latvian folk songs in Johann Gottfried Herder's manuscripts collection}

\section{Beata Paškevica}

Keywords: Heinrich Baumann, Gustav Bergmann, Enlightenment, Jakob Benjamin Fischer, folk song, Johann Gottfried Herder, August Wilhelm Hupel, Latvian folk songs, Volkslieder / Stimmen der Völker in Liedern

The handwritten Latvian folk songs in Johann Gottfried Herder's manuscripts collection at the Prussian Cultural Heritage Manuscript Department of the Berlin State Library (also known as "Livonian collection", as titled by Leonid Arbusow) are a testimony of the folk songs collection campaign at Herder's request in 1777 and 1778.

The authors who responded to Herder's request and collected, commented, and translated Latvian folk songs have been identified in some cases, but there are also manuscripts of unidentified authorship; the identity of their authors has been widely discussed in previous studies. In the present study, handwritings in documents held at the National Library of Latvia, the Academic Library of the University of Latvia, the National Archive of Latvia, and the Historical Archive of Latvia have been compared 
and all collectors of Latvian folk songs in Herder's personal archives have been identified. It has been found that the unidentified handwritings belong to Heinrich Baumann, Gustav Bergmann, Jakob Benjamin Fischer, and August Wilhelm Hupel. It has been discovered that manuscripts No. 50 and No. 53.1 of Herder's personal archives were written by Gustav Bergmann; manuscript No. 51 was written by Jakob Benjamin Fischer (it includes texts from the 50th manuscript by Baumann and the 52nd manuscript by Bergmann as well as some original texts which were missing in both Baumann's and Bergmann's manuscripts); manuscript No. 52 was written by Gustav Bergmann, and manuscript No. 53.2 was written by August Wilhelm Hupel.

Herder selected parts of manuscripts No. 50, 51, and 52 to publish them in a separate section titled "Fragments of Latvian Songs" (Fragmente lettischer Lieder) in his collection "Folk Songs" (1778/1779). Encompassing six texts, "Fragments of Latvian Songs" is the first set of Latvian folk songs in Herder's volume. There is also a second collection, titled "The Song of the Spring" (Frühlingslied) in which five texts are included. The original handwritten texts of "The Song of the Spring" have not been found in Herder's personal archives in the Berlin State Library; therefore it must be assumed that Herder received yet another handwritten collection of folk songs which has been lost. For this reason, the number of songs in the lost collection remains unknown as well. Considering that "Fragments of Latvian Songs" were selected from eighty submitted texts (which included different variations of the same song), we can assume that "The Song of the Spring" has been similarly selected from a wider amount of texts according to rigid principles known only to Herder himself. Thanks to the cooperation of Livonian authors, Herder had a broad collection of Latvian folk songs in his possession. 